\title{
El Cronotopo del Turismo: Espacios y Ritmos ${ }^{1}$
}

\section{The Chronotope of Tourism: Spaces and Rhythms}

\author{
Antonio Miguel NOGUÉS-PEDREGAL \\ Grupo de Investigación en "Cultura, turismo y (cooperación al) desarrollo - Culturdes" \\ Departamento de Ciencias Sociales y Humanas \\ Universidad Miguel Hernández \\ amnogues@umh.es
}

Recibido: 5 de agosto de 2011

Aceptado: 10 de noviembre de 2011

\begin{abstract}
Resumen
De acuerdo con las previsiones de la Organización Mundial del Turismo - OMT en 2012 sobrepasaremos la cifra de mil millones de llegadas de turistas. Este complejo conjunto que por abreviar denominamos 'turismo' es una forma distintiva de utilizar el espacio (el territorio, el paisaje) y el tiempo (el ritmo, el suceder). Es también un agente globalizador de primer orden porque coadyuva a que la 'globalización' se extienda allí donde las nuevas tecnologías de la comunicación no alcanzan todavía. El concepto de 'cronotopo' de Bajtín nos sirve para caracterizar la manera en la que en contextos turísticos se combinan los elementos donde se concretan el espacio y el tiempo. Todo nos lleva a pensar que el Turismo es la creación más perfecta y sofisticada del Capitalismo, por cuanto no sólo consume lugares y territorios, esculpe paisajes o perpetúa relaciones de dependencia sino que, produce sentidos y significados, y convierte al lugar a través del espacio turístico actualizando los espacios y los ritmos de acuerdo con los principios definidos por el Mercado Global. En función de lo anterior se hacen consideraciones sobre la distintividad del quehacer etnográfico en entornos turísticos.
\end{abstract}

Palabras clave: turismo, cronotopo, significación, práctica antropológica, globalización.

\begin{abstract}
According to the World Tourism Organisation, international tourism will reach one billion in 2012. This complex compound of practices and devices that we name 'tourism' is a distinctive way to use space (territory, landscape) and time (rhythm, occurrences). Tourism is an important globalising agent because it contributes to extend globalization to where new information and communication technologies have not reached yet. Bakhtin's concept of 'chronotope' is valuable to characterize the way spatial and time elements are combined in

${ }^{1}$ Algunas de las ideas aquí recogidas han sido publicadas en distintas fases de su maduración en los siguientes textos: "Etnografías de la globalización. Cómo pensar el turismo desde la antropología". Archipiélago. Cuadernos de crítica de la cultura, 68: 33-38 (2005); "Genealogía de la difícil relación entre antropología social y turismo". Pasos. Revista de Turismo y Patrimonio Cultural, 7:43-56 (2009); y en "Esculpiendo paisajes del deseo", en Escultura y paisaje. Support/ surface, Kosme de Barañano y Pilar Escanero, pp. 73-80. Fundación Cañada Blanch, Alicante (2011). Estos textos están alojados en http://umh-es.academia.edu/amnogues.
\end{abstract}


tourism contexts. The data induce that Tourism is the most perfect and sophisticated elaboration of Capitalism for it consumes places and territories, shapes landscapes and perpetuates dependency relationships. Besides, it also produces sense and meanings, it mediates place through tourism space and update spaces and rhythms according to the guiding principles of Global Market. To conclude some notes on the distinctiveness of anthropological practices as carried out in tourism environments are made.

Keywords: tourism, chronotope, signification, anthropological practice, globalisation.

Referencia normalizada: Nogués Pedregal, A. M. (2012) El cronotopo del turismo: espacios y tiempos. Revista de Antropología Social, 21: 147-171.

SUMARIO: 1. Exordio. 2. Esculpiendo los paisajes del deseo. 3. El turismo global. 4. El cronotopo del turismo. 4.1. El cronotopo del veraneo. 5. El turismo y la Antropología en un mundo globalizado. 6. Referencias bibliográficas.

\section{Exordio ${ }^{2}$}

Al espacio reivindicado lo llamamos 'territorio'. El territorio siempre lo es de alguien: de un grupo étnico, de un colectivo okupa, de una banda juvenil... o, en último extremo, de esa unidad de producción y gestión administrativa de la Realidad que conocemos con el nombre de Estado. Cuando el territorio es transformado por los seres humanos en objeto de deseo, sea para el deleite estético, sea para la ocupación física en forma de terrazas agrícolas o de residencias turísticas, lo llamamos 'paisaje'. El paisaje es, pues y ante todo, el resultado del propósito humano esculpido sobre la materia que constituyen los sueños: el deseo. En la actualidad, ese denso conjunto de dispositivos socio-tecnológicos ${ }^{3}$ que facilita el transporte, alojamiento y entretenimiento de ciertos grupos sociales alejados de su cotidianeidad así como los procesos y prácticas que inducen y que, por abreviar, llamamos 'turismo', es uno de los principales incitadores de deseo, de paisajes y de tiempos para su disfrute, en definitiva. Y a aportar algo a su comprensión dedicaré este artículo.

\section{Esculpiendo los paisajes del deseo}

Según la información incrustada en el archivo original la imagen fue tomada con mi pequeña cámara de viaje Sony DSC-P92 a las 15:58 del 26 de marzo de 2005 (fotografía 1). Recuerdo que en aquel viaje mi mujer y yo tuvimos que pernoctar en Berlín para volar desde Alicante, donde vivimos, a Ljubljana, en cuya universidad impartía un seminario. Hacía años que habíamos visitado Berlín y — de la necesidad, virtud - nos tomamos la imposición de la aerolínea como una oportunidad para volver y pasar allí unos días. Porque a diferencia de las 'aerolíneas de bandera'

2 "Principio, introducción, preámbulo de una obra literaria, especialmente primera parte del discurso oratorio, la cual tiene por objeto excitar la atención y preparar el ánimo de los oyentes"

${ }^{3}$ Esta adjetivación me parece más inclusiva que la que yo venía utilizando de "dispositivos simbólicos y técnicos" y se la debo a Matilde Córdoba, coordinadora de este monográfico. 


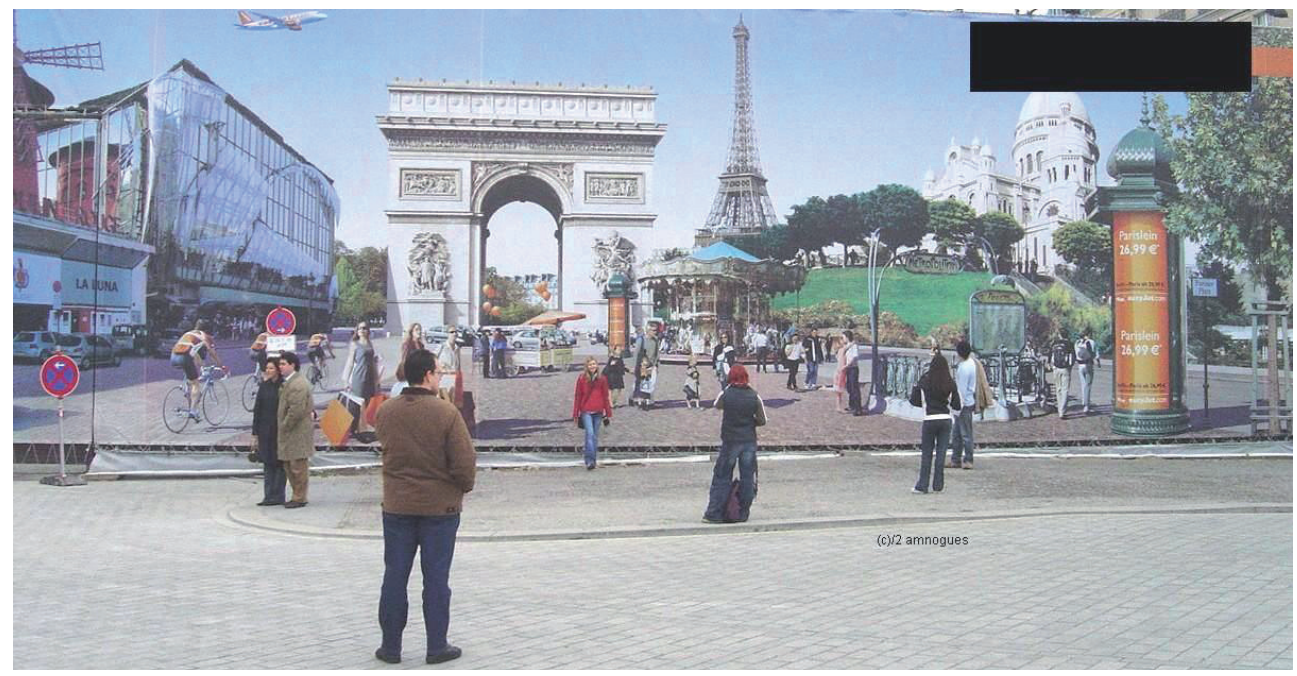

Figura 1. Una experiencia des-localizada: ¿fue en París o en Berlín?

cuyas rutas solían responder a razones de corte geopolítico ${ }^{4}$, las líneas de bajo coste se adaptan rápidamente al oligopolio de los turoperadores internacionales que son los que generan los flujos turísticos (Aguiló, Alegre \& Sard 2003; Cavlek 2005). Una flexibilidad que perpetúa las dependencias interterritoriales, y unas prácticas serializadas que producen lo que el elitismo sociológico se obstina en llamar 'turismo de masa' o, peor aún 'turismo de masas', como si no hubiésemos aprendido nada de las enseñanzas de la Escuela de Frankfurt.

Basta observar la información de vuelos para confirmar los principios sobre los que el Mercado Global establece las condiciones que organizan el tiempo y el espacio en la actualidad, y que evidencia la interconexión de los territorios en un doble sentido. Por un lado, la inmediatez en la información que se nos facilita sobre lo que ocurre en determinadas zonas del Planeta, acelera el ritmo de nuestro cotidiano; y, por otro, las explicaciones que acompañan a la información muestran la infinita red causal de ámbito planetario en la que estamos sumergidos.

Conozco algunos aeropuertos y me gusta caminarlos para entretener, aprovechando, el tiempo de espera. En estos no-lugares, como se empeña en etiquetarlos cierto snobismo, he comprobado en decenas de paneles que, en su mayoría, los horarios de las líneas de bajo coste se adaptan más a los ritmos diarios de los viajeros que se dirigen hacia la periferia turística que a la inversa. Una visita al Aeropuerto Internacional de Alicante que tiene casi como único mercado el turístico de bajo coste lo confirma. El control de los ritmos y de la movilidad de las poblaciones,

${ }^{4}$ Es oportuno recordar aquí que, al momento de repasar estas líneas (diciembre 2011), el sindicato de pilotos - SEPLA rechaza la creación de la línea de bajo coste Iberia-Express. En su argumentario apela a cierto nacionalismo económico y explica que Iberia entregará los activos a British Airways y convertirá "a España en un territorio low-cost". 
concretado en las estrategias horarias del oligopolio turoperadores-compañías aéreas, sigue haciendo difícil la fácil conexión entre periferias.

Air Berlin era la que ofrecía la ruta más sensata para llegar a Ljubljana; si bien había que hacer una parada técnica en el aeropuerto de Son Sant Joan, pernoctar en Berlín, y tomar un vuelo tempranero para Eslovenia. En esta época de desregulación y desaparición de los monopolios, las líneas de bajo coste son el mejor ejemplo de cómo las nuevas tecnologías determinan las posibilidades de desarrollo turístico de los territorios.

Quizás por esto no me extrañó que una línea aérea de bajo coste me ofreciese en Berlín ser parisino por tan sólo 26,99€. En un panel publicitario descomunal los iconos más emblemáticos de París jugaban un endemoniado laberinto de verdades y simulacros que me sumían en un viaje imaginario y momentáneo a la capital del Sena. Atrapados por aquel frenético juego de imágenes, una pareja que transitaba por el bulevar se retrató junto al Arco de Triunfo, mientras un joven le relataba a su pareja algunos detalles de su último viaje a París. El avión había dejado atrás las aspas del Moulin Rouge y pronto sobrevolaría los volúmenes de Sacré Coeur. Disfruté mi silenciosa y anónima observación desde un emplazamiento privilegiado. Muchos viandantes se detenían y otros se desplazaban unos cientos de metros para fotografiarse frente a la eterna silueta de la Torre Eiffel.

Una vista muy local que adquirió todo el esplendor de su dimensión global cuando consideré que aquel enorme panel publicitario se encontraba en la Pariser Platz, al comienzo de la conocida avenida Unter den Linde, y justo detrás del icono del globalismo: la Puerta de Brandenburgo en Berlín. Percibí que mi aquí y ahora quedaba contextualizado en una escala espaciotemporal de orden social superior; que se había densificado la información hasta el límite de difuminar la realidad del 'territorio turístico' en el que me encontraba (Berlín), no con su propia representación escénica, sino con aquella otra más lejana a la que se me invitaba y que se me presentaba como el 'escenario turístico' donde reside el objeto de mi deseo (París).

No fue la publicidad ni sus dimensiones lo que llamó mi atención, sino la interacción que los paseantes mantenían con dicho objeto. Le daban sentido de manera dialógica: contemplé la absoluta identificación de unas personas que interactuaban con una descomunal imagen como si (de la misma manera, con las mismas acciones) fuese real. Me encanta la pareja de la izquierda, que aún detuvo a un tercero para que los fotografiase y que captura a la perfección la noción de espectáculo de Debord: "una relación social entre las personas mediatizada por imágenes". Mirando fijamente a la cámara, abrazados frente al objetivo, juegan con su imaginación y sus deseos, mientras se prometen que el próximo viaje será a París. La pose de la chica en el centro de mi fotografía es espectacularmente real. Su acompañante le indicaba donde colocarse mientras hacía escorzos buscando el encuadre bajo el Arco del Triunfo: auténtico punto de fuga de toda la composición. Poco después se vuelven las tornas y se repite el ritual. Esperé a que me pidieran que las retratase y así charlar con ellas, pero no hubo suerte. Recogieron su mochila y se encaminaron hacia la Puerta de Brandenburgo. 
Miro con especial atención a la joven de la derecha que sigue con suma atención las explicaciones de su pareja, a quien retrata instantes después. Él le explica con sumo detalle y un amplio repertorio de deícticos que sobre esta colina de Montmartre, en el distrito 18 de París, se yergue imponente la Basílica del Sacré Coeur (Sagrado Corazón), y que los más de 300 escalones que ascienden hasta allí le merecieron mucho respeto y que por eso decidió utilizar el funicular. Pero después del relajado paseo por el barrio de Montmartre, le gustó la sensación de bajarlos. Sobre todo se detiene y le explica con cuidado la entrada del Métropolitain ante la que se encuentran, mientras perfila con el movimiento de su mano los detalles modernistas. Le cuenta que es uno de los 84 accesos de Art Noveau que diseñara Hector Guimard a caballo entre los siglos XIX y XX. Apunta que se parece mucho a la entrada de la estación de Pigalle, en el barrio del mismo nombre. Este barrio le encanta porque multitud de visitantes se arremolinan en torno a los locales que ofrecen espectáculos eróticos y las luces de colores que hacen gala al apelativo de París: la Ville lumière. “¡Mira!, ¡allí!” — exclama con un guiño mientras señala el lado izquierdo del cartel un giro rápido de cabeza: " $i$ estamos en el Boulevard Clichy donde se encuentra el Moulin Rouge!” Ella, atenta, no presta atención a la insinuación, pero le sigue con su mirada.

Lo más espectacular es, sin duda, la socarronería de quien buscó la extrema complementariedad entre la realidad y la ficción, y colocó una señal de tráfico de prohibido parar. Siempre he pensado que esta intención por difuminar las fronteras entre el cartel y la avenida adquiría un especial sentido en ese lugar donde, el 9 de noviembre de 1989 asistimos por televisión a la caída del Muro. Quien puso la señal fue meticuloso y se preocupó por alinear ambas: buscaba, y desde luego lo consigue, realzar la perspectiva y confundir al viandante. "No se detenga, no estacione: ¡continúe!"

Unas jóvenes salen con compras de unas galerías comerciales que no reconozco y se apresuran por pisar Berlín. Unos ciclistas emulan la etapa final del Tour y se adentran en la avenida des Champs-Élysées. Una familia acaba de recoger a sus hijas del colegio en el que estudian y vuelve a casa paseando. La más pequeña protesta porque quiere un algodón dulce y la madre le dice que después de merendar le comprará uno. Unos enamorados se despiden con un eterno beso junto a la entrada del metro... y mientras, el carrusel gira que gira.

Una conjunción de tiempos y de espacios dispuestos para conectar presencia y ausencia, romper la última frontera entre el aquí y el allí, lo imaginado y lo real, los deseos y las frustraciones. Entiendo que unas acciones así solo adquieren sentido en el marco de las condiciones de existencia social que determina el cronotopo del turismo: unas coordenadas espacio-temporales en las que se privilegia la diversión y el entretenimiento. Unos momentos, un contexto de enunciación en el que se puede ser campesino o rey/reina por un día, en el que se suspenden las obligaciones estructurales, cuando se alteran los horarios de lo cotidiano, donde aparentemente se difuminan las diferencias sociales y cuando el espacio se comprime hasta fundir el allí y el aquí / el ahora y el entonces como en un parque temático. No voy a negar que el gigantismo del cartel invitara al mismo juego de simulacros si apareciese 
colocado en otro punto de la ciudad, pero estoy convencido de que era su exacta ubicación en un sitio turístico de primera magnitud lo que le daba ese sentido que hacía que la gente se retratase como si de los originales se tratase. Su ubicación en la Pariser Platz, la inmediata presencia de la Puerta de Brandenburgo, los tilos de la famosa avenida berlinesa y, sobre todo, el uso que los viandantes hacían del cartel, lo actualizaron en ese locus inalienable donde la experiencia turística adquiere su pleno sentido: el consumo in situ vía observación o degustación del objeto original o, vía adquisición — por compra o por registro fotográfico - de su réplica.

Sé que si hubiese tenido mi Nikon D90 el archivo tendría más resolución pero, por algún motivo que no recuerdo ahora, no la llevamos en un viaje que en el mejor de los casos solo supondría algo de 'turismo académico'. Tampoco puedo afirmar que no tuviese intención de hacer trabajo de campo porque como siempre me recuerda mi mujer, desde que viaja conmigo y lee mis textos, el turismo no es lo que era. De hecho, como le repetí varias veces, estoy convencido de que si nos hubiésemos demorado un poco más habría visto formarse alguna cola para sacarse una foto junto al Arco del Triunfo, pero no quería quedarme allí solo. Por cierto, el chico en primer término y de espaldas a mi cámara no se inmuta; él sí está solo y ha anotado algo en una libreta que guarda en el bolsillo. No sé, quizás estuviera haciendo trabajo de campo. Debería haberle preguntado.

La concurrencia de estas dos circunstancias me llevará a escribir, siquiera brevemente y como reflexión final de este artículo, sobre la inteligibilidad y distintividad de la práctica antropológica en un contexto de turismo global. Ahora, y con la descripción del cartel muy presente, exploraré algunos aspectos definitorios del turismo global y del cronotopo en el que adquiere su sentido pleno.

\section{El turismo global}

Sé que no añado nada cuando afirmo que el Turismo — así, en mayúsculas, como si fuera un nombre propio que no respondiese a circunstancia histórica alguna, como una concreción fuera de lugar- manifestado en sus más extravagantes modalidades y denominaciones es un agente globalizador de primer orden. Todo los datos apuntan a que el Turismo es, quizás, la creación más perfecta del Capitalismo por cuanto no sólo consume lugares y territorios, esculpe paisajes sobre la materia que constituyen los sueños: el deseo, o perpetúa relaciones de dependencia sino que, en la dimensión expresiva, produce sentidos y significados, y convierte al lugar a través del espacio turístico actualizando ${ }^{5}$ los espacios y los ritmos de acuerdo con los principios definidos por el Mercado Global. Entre estos principios destacan los referidos a la división internacional del trabajo por territorios y la desregulación de los mercados, que se concretan en el aumento de la demanda del llamado 'turismo residencial', la desestacionalización y diversificación tipológica de las vacaciones en estancias más cortas a lo largo del año, la aparición de Internet y los nuevos mode-

${ }^{5}$ Este verbo denota un sentido no esencialista, lo que sí hacen verbos como 'transformar' o 'cambiar'. 
los de distribución y organización, o el surgimiento de las compañías de bajo coste. Y todo junto a la continua aparición de nuevos territorios y productos turísticos.

Más allá de las modalidades tradicionales (i.e. solyplaya, rural, urbano, etc.), y de aquellas que son vividas como alternativas (i.e. turismo solidario, eco-turismo, agro-turismo, etno-turismo, turismo nativo, etc.), e incluso de otras tendencias como el "dark tourism" que organiza viajes y estancias en sitios donde la humanidad ha sufrido lo indecible (i.e. campos de concentración, batallas sangrientas, desastres naturales...), o el kojo moe $e^{6}$, que conocí hojeando el Wall Street Journal, muestran que esa forma de mover capital económico que llamamos Turismo es un medio que posibilita que cualquier lugar del mundo pueda convertirse en un destino turístico deseable. Pocos dudan que esto coadyuve a que lo que hemos dado en llamar 'globalización' - ese fenómeno que intensifica y, sobre todo, evidencia la interdependencia que hay entre territorios y sus pobladores a nivel planetario, y en casi todos los ámbitos de nuestra vida - consiga extenderse allí donde la cobertura de las nuevas tecnologías de la comunicación no ha llegado todavía. Una realidad que ilustra bien el trabajo Chambre d'hôtes dans le Sahel (58') del realizador francés Christian Lallier (2001): un documental que muestra cómo una remota aldea al norte de Burkina Faso se prepara para la llegada de una iniciativa de turismo solidario y los promotores enseñan a sus habitantes a gestionar los servicios de alojamiento y manutención, a realizar visitas guiadas y a producir artesanía. Más impactante, y con una segunda parte que invita a la reflexión, resulta el documental Cannibal Tours (72') del australiano Dennis O'Rourke (1988) sobre los turistas de un crucero de lujo que baja por el Sepik a través de los bosques tropicales de Papúa-Nueva Guinea. O el más reciente Framing the Other: when strangers meet in the name of tourism (25') realizado por Ilja Kok y Willem Timmers de la productora I-Camera-You sobre la reconstrucción de los Mursi del valle del Omo en Etiopía como producto turístico? Unos documentales que acompañan bien el relato Le clou de la croisière que Clastres publicara en Les Temps Modernes (1971). En este texto Clastres describe el juego de espejos y engaños que esconden las transacciones entre los que buscan la autenticidad de lo exótico y los que escenifican la autenticidad en destinos turísticos. El ejemplo más extremo de que el Turismo llega hasta los últimos rincones del Planeta es el conocido como "first contact tourism". Esta modalidad ha encontrado en territorios del Pacífico, especialmente en Papúa Nueva Guinea, un nuevo nicho de mercado como recoge el documental First Contact (60') producido por Indus Films Ltd. y emitido en 2006 por la British Broadcasting Corporation Four (BBC4). Por unos 8.000 US\$ el promotor de la iniciativa despierta el deseo de los más

6 “Al contrario que los turistas que visitan las fábricas de la Toyota Motor Corporation y de otros fabricantes japoneses, los seguidores del kojo moe muestran escaso interés por los procesos que se realizan en el interior. Estos se entusiasman con el intrincado haz de tuberías que rodean las siderúrgicas o las cilíndricas chimeneas que expulsan vapor". Wall Street Journal de 24 de enero de 2011.

${ }^{7}$ Mientras repaso estas líneas por última vez me llega por correo electrónico la noticia de que Survival International denuncia los 'safaris humanos' en los que a mujeres y niños jarawa (islas Andamán) se les obliga a bailar para los turistas: http://www.survival.es/noticias/8028 
aventureros con esta sugestiva invitación: "En esta era de la comunicación global, tecnología avanzada y viajes en alta velocidad, todavía existen bolsas de humanidad 'sin contacto' con el mundo exterior"s.

De acuerdo con esto, el conocimiento de ese conjunto de dispositivos sociotecnológicos que, por abreviar, llamamos 'turismo' colabora en la promoción del actual régimen de producción del espacio y el tiempo que viene facilitado (1) por las nuevas tecnologías de la comunicación que "organizan el tiempo y el espacio de forma que conectan presencia y ausencia" (Giddens, 1990:14) y aceleran las relaciones sociales, y (2) por la accesibilidad (en precios y horarios) y celeridad en los transportes (salir de Berlín o Londres al atardecer, pasar la noche en una discoteca de Ibiza y volver a dormir a casa). Por tanto también puede - iy debe! - abordarse desde las ciencias sociales y las humanidades como otro de los modos que el capital económico emplea para intensificar y evidenciar la interdependencia que hay entre los habitantes del Planeta. Esta idea, insisto, no es nueva, y está muy aceptada entre los investigadores que nos acercamos a esta temática. Esta aceptación no se debe tanto a la asunción crítica de sus implicaciones, sino a la inercia que imprime a nuestro análisis el uso de una literatura que aborda y habla del Turismo como sujeto agente'. El reiterado empleo que se hace de la palabra 'turismo' en función de sujeto gramatical es constante en los textos —al menos en los que resultan más accesibles y recomendados según los dispositivos (i.e. bases de datos) y criterios (i.e. factor de impacto) sancionados por el mantra de "la economía del conocimiento global" o "capitalismo académico" (cf. Hoffman, 2011; Wright y Rabo, 2010)—. Es una sutileza gramatical que porta un doble paralogismo. En primer lugar induce a pensar que la extensión planetaria de las distintas modalidades de turismo vehicula la intersección de los procesos locales y las dinámicas globales. Para muchos esta incontestable realidad es la demostración de que la Globalización efectivamente existe y es inevitable. Y, en segundo lugar, la presentación gramatical como sujeto caracteriza al turismo como un fenómeno que es independiente de la producción social y de su dimensión espacio-temporal. No en vano en la literatura se utiliza el mismo término para englobar tanto las prácticas sociales de la nobleza y burguesías españolas en el Cantábrico como el botellón de jóvenes europeos en la Costa Brava. Siendo mínimamente riguroso no creo que debamos recurrir al mismo término; aunque reconozco que facilita el necesario ejercicio de síntesis que demanda cualquier texto. No obstante nunca está de más recordar esto porque ayuda a mejorar la precisión de nuestros análisisLo más interesante del paralogismo del turismo como sujeto es que sugiere que el turismo en Santander y en Lloret de Mar responde a los mismos procesos y que sus diferencias son solo formales. Esta construcción del turismo como una 'concreción fuera de lugar' lleva a que, quizás de manera no deseada, los resultados de investigación ayudan a validar esa ideología — llamémosla

${ }^{8} \mathrm{http}: / /$ www.papua-adventures.com/first-contact.html

${ }^{9}$ También es cierto, como ya demostraran hace décadas Mario Gaviria (1974), Antonio Mandly (1977), Dennison Nash (1978), Francisco Jurdao (1979) o Stephen G. Britton (1982), que se puede hablar del turismo como de otro agente histórico del capitalismo y desarrollar una comprensión crítica de los actores que alientan y propician su expansión plantearia. 
'globalismo' - que imagina que los grupos humanos funcionan de acuerdo con las leyes del libre-mercado, que defiende la internacionalización y expansión a lo local de estas leyes, y que, en definitiva, legitima las dinámicas de la Globalización ${ }^{10}$. De hecho, el reconocimiento por parte de la comunidad científica de la intersección entre lo global y lo local no se refleja, aún, en el planteamiento teórico desde los que se estudia el turismo. Esta ausencia explicaría el predominio y pervivencia en las ciencias sociales de los modelos estáticos para el estudio del Turismo (Meethan, 2003). Por esto creo en la necesidad de devolver al turismo su carácter histórico: su carácter de producto social en el marco de las coordenadas espacio-temporales concretas que le dan sentido. Una opción es estudiar el Turismo, además de como otra de las dinámicas inducidas que aprovecha los dispositivos socio-tecnológicos existentes para expandir la versión capitalista de la Realidad, como un contexto en el que ocurre lo cultural en tanto que proceso de significación y tratamiento de las diferencias. Estudiarlo, en fin, como otro de los nombres del Poder ${ }^{11}$.

Además, y por otra parte, esta adhesión no intencionada al globalismo ha provocado a su vez un tenue y, digamos, curioso desplazamiento epistemológico en el campo de los estudios del turismo (tourism studies) ${ }^{12}$. Del estudio del hecho/objeto ‘turismo' como fenómeno externo - agente - que inducía unas dinámicas particulares en los destinos o que permitía la relocalización constante del capital económico (momento A), hemos pasado a subrayar al Turismo, en sus distintas adjetivaciones, como vehículo para el conocimiento del Otro y, especialmente, para el desarrollo de los territorios y sus habitantes (momento B). Pondré algunos ejemplos.

Hay iniciativas muy críticas con el Turismo como por ejemplo el turismo comunitario dinamizado desde el Foro de Turismo Responsable, o las englobadas por el concepto de pro-poor tourism ${ }^{13}$ (cf. Duim, 2008), o la propuesta de 'turismo militante' que nace para contrarrestar la despolitización experimentada por el 'turismo solidario' (Gascón 2009), se enfrentan ante una paradoja. El capital económico ha estado - y si no lo remediamos entre todos parece que seguirá estando- siempre ávido de nuevos segmentos de mercado a los que "poner en valor" para darles el correspondiente uso turístico. Es por esto que la puesta en marcha de cualquier

${ }^{10}$ Donde el internacionalismo aboga por la cooperación entre los pueblos, el globalismo plantea la competencia entre los territorios y sus habitantes. Mientras que el adjetivo planetario refiere a la extensión física de cualquier fenómeno, la noción de global — como es utilizada por el globalismo - privilegia la expansión del capital económico frente a otras dimensiones de lo social.

${ }^{11}$ Defino poder como la capacidad para fracturar la realidad distinguiendo unos hechos de otros (de manera que se puedan organizar en categorías culturales), para inducir la conexión entre estos hechos (de forma que sean significativos), para mantener la estabilidad de estas conexiones (dando continuidad) y, en consecuencia, para orientar las prácticas en sociedad (dando sentido a la vida social).

${ }^{12}$ En 1977 Jeremy Boissevain habla de las carencias epistemológicas que evidenciaban los estudios antropológicos porque "apenas podemos distinguir de manera convincente los efectos del turismo de aquéllos causados por otras fuerzas contemporáneas de cambio social" (cit. en Crick, 1989: 335).

${ }^{13}$ El término Pro-poor Tourism (PPT) fue empleado por primera vez en un informe del Departamento para el Desarrollo Internacional del Reino Unido en 1999 (Duim, 2008:179). 
conjunto de actividades humanas que implique su realización en otro tiempo

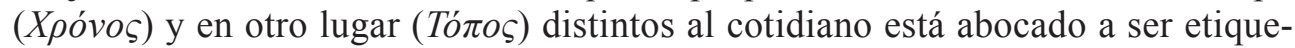
tado con el nombre de 'turismo' y, por tanto, a ser gestionado y comercializado de acuerdo con los principios y lógicas del Mercado Global.

De esta batalla lingüística nace una paradoja: cualquier propuesta que quiera distanciarse de las prácticas turísticas promovidas por este mercado global requiere de una etiqueta que las distinga. Sin embargo, y mediante un proceso de objetivación que todos conocemos bien (cf. Berger y Luckmann, 1966), será la existencia ideal de esa misma etiqueta, el deseo que despierta su obtención y, sobre todo, el proceso al que haya que someterse para verificar si las prácticas propuestas se adecuan al código de conducta que avala la etiqueta ${ }^{14}$, lo que formalice dichas prácticas y desvele su potencia mercantil. La Red de Turismo Comunitario de América Latina recibe al internauta en el "portal de las culturas vivas de América Latina" con el objetivo declarado de fomentar las "oportunidades de negocios de las comunidades de América Latina, para mejorar sus condiciones de vida y de trabajo"15. En el orden actual de las palabras y las cosas, la solución a esta paradoja trae muchos quebraderos de cabeza, pero no desanima a nadie afortunadamente.

La aceptación de esta imposibilidad unido al creciente número de personas que somos seducidas para viajar y conocer otras gentes es lo que, probablemente, ha llevado a la Coordinadora Valenciana de ONGD a trabajar un abanico de propuestas que cubren "cursos de formación en el terreno, turismo solidario, voluntariado de proyectos en cooperación internacional, voluntariado de acción humanitaria, campos de trabajo, brigadas solidarias, vacaciones solidarias, campos de solidaridad, turismo responsable...", aunque planteados en "clave de solidaridad" como explica de manera excepcional el vídeo de la Fundación Hazloposible (mayo 2010) ${ }^{16}$. En este marco de pragmatismo encuentran su explicación iniciativas como las que vinculan el comercio justo y el turismo; los esfuerzos por acercar ámbitos realizados desde la Red Internacional de Investigadores en Turismo, Cooperación y Desarrollo; o la búsqueda de nuevas formas de abordar el turismo impulsadas por la Fundación de Turismo y Cooperación, cuyo patrono es el Grupo de Agencias de Viajes Independiente - GEA. En esta línea se puede situar también la Estrategia Cultura y Desarrollo de la Agencia Española de Cooperación Internacional para el Desarrollo - AECID (Moragues, 2007), en la que enmarcamos los proyectos realizados desde el grupo de investigación "Cultura, turismo y (cooperación al) desarrollo - Culturdes" (cf. Soler et al. 2010; Nogués et al. 2010).

14 "La certificación BIOSPHERE, promovida por el Instituto de Turismo Responsable (ITR), reconoce y certifica establecimientos turísticos que han hecho de la gestión sostenible del turismo el eje y centro de su actividad y que, por ello, son ejemplos de sostenibilidad en el sector a nivel internacional [...] es una certificación voluntaria basada en los principios del desarrollo sostenible mediante criterios concretos sobre el comportamiento ambiental, cultural y socioeconómico, concedida a establecimientos a nivel planetario".

${ }^{15} \mathrm{http}: / /$ www.redturs.org.

${ }^{16} \mathrm{http}: / /$ www.youtube.com/watch?v=LtzQPN3VtkI 
No obstante es importante subrayar que a diferencia de las modalidades que adjetivan el turismo desde el mundo de las motivaciones de los viajeros calificándolos como solidario, rural, cultural, agroturismo, étnico, etcétera con el objetivo de segmentar la demanda y generar nichos de mercado, la mayoría de los adjetivos empleados por estas propuestas de carácter más adaptativo cualifican propósitos y maneras de desarrollar el hecho del turismo. Si bien estas propuestas pueden resultar, quizás, un tanto complacientes con el actual orden de cosas, indican a mi juicio que estamos en un momento $\mathrm{C}$ de la relación entre el turismo, las ciencias sociales y los principios del humanismo cristiano de la cooperación internacional. Un momento caracterizado por la evidencia de lo trans-, que impugna la simetría de la relación causa-efecto, supera el principio dialéctico más clásico de la resolución de las contradicciones en sucesivas fases, y objeta los retazos esencialistas que destilan ciertos análisis del turismo (Nogués, 2011). Una aproximación dialógica (Ooi, 2002) para comprender los vínculos que las distintas modalidades de turismo establecen entre los procesos locales y las dinámicas globales, y que conforman un cronotopo específico, un mundo de sentido inteligible y concreto distintivo.

Para desentrañar las características de esta inducción espectacular (Debord) que es el Turismo, he encontrado inspiración en los textos de Mijail M. Bajtín especialmente en su modelo dialógico de significación y en su concepto de 'cronotopo' ${ }^{17}$. En el cronotopo, sostiene Bajtín, tiene lugar la unión de los elementos espaciales y temporales en un todo inteligible y concreto, lo que supone visualizar las relaciones sociales y culturales en términos de espacio y tiempo, algo especialmente relevante si hemos de estudiar al Turismo como esa Realidad planetaria en la que se ha convertido.

\section{El cronotopo del turismo}

El espacio y el tiempo son los determinantes necesarios de la existencia humana. Todo hecho humano lo es en un momento y lugar concretos, y no puede no-serlo. En "Las formas del tiempo y del cronotopo en la novela" Mijail Bajtín llama cronotopo "a la conexión esencial de relaciones temporales y espaciales asimiladas artísticamente en la literatura [...] En el cronotopo artístico literario tiene lugar la unión de los elementos espaciales en un todo inteligible y concreto" (1937:237238). El cronotopo es, por así decirlo, la circunstancia que marca las condiciones del discurrir social, y es resultado de una manera particular de combinar los 'hechos' (elementos, objetos, imágenes, acciones) en los que se manifiestan la obligada espacialidad y temporalidad de la existencia humana. Es una matriz en la que las prácticas cotidianas adquieren su sentido, y se conforma a partir del uso que se hace de los 'depositarios' (Frondisi) donde reside el espacio y el tiempo en los que ocurren dichas prácticas. Por ejemplo, y como he indicado, el cartel anterior solo adquiere

${ }^{17}$ En un primer borrador de este artículo traté el concepto de "carnavalización”, pero en una comunicación personal el profesor Antonio Mandly me recordó que "la idea de carnavalización de Bajtín impide la comercialización de los turistas, ya que construye sujetos que se integran en la vorágine festiva, cosa que no compensaría a la construcción de la realidad espectacular mercantil como simulacro". 
su pleno sentido orientando la acción turística hacía París exactamente en ese sitio: exactamente en la Pariser Platz. Y porque se esperaba que esto pudiera ser así, creo no errar al suponer que la agencia de publicidad diseñó el cartel y la posibilidad de su ubicación de manera complementaria; es decir, se sabía con total seguridad que en ese sitio habría personas con el papel de turista global muy asumido y con disposición a participar - de manera consciente o no- del espectáculo mercantil. Esta combinación de circunstancias causada por el propósito de la aerolínea en despertar el deseo de viajar son las que, en su realización, conforman el cronotopo del turismo. El concepto de cronotopo sirve pues para caracterizar la manera - género literario- en la que se combinan las distintas formas de tratar el tiempo y el espacio.

Esta matriz espacio-temporal no es trascendental al modo de Kant. Muy al contrario, tal como entiendo a Bajtín, el cronotopo es un producto de las condiciones históricas que marcan no solo dónde se deposita la inevitabilidad del espacio-tiempo sino, muy especialmente, la manera en la que estos despositarios se relacionan unos con otros, haciendo que el conjunto resulte inteligible y teja esa densa red de significados en la que, de acuerdo con Weber, estamos inmersos.

Por eso, en tanto que marca cuáles son las condiciones de la significación, es decir, las condiciones del proceso por el que los hechos que componen el mundo se vinculan unos a otros sirviéndose mutuamente como referentes, pensar con la noción 'cronotopo' ayuda a comprender mejor eso que, por abreviar, llamamos 'turismo'.

Aquí retomo la definición de turismo que ya aparece en el exordio: el conjunto de dispositivos socio-tecnológicos que facilitan el transporte, alojamiento y entretenimiento de ciertos grupos sociales alejados de su cotidianeidad así como los procesos y prácticas que inducen. Así descrito la idea de turismo queda bastante diluida y muy alejada de la que tenemos en el lenguaje cotidiano. Sin embargo es una definición muy fácil de concretar: son muchas las investigaciones que demuestran cómo el turismo se ha convertido en la realidad absoluta que determina la elaboración de políticas públicas, condiciona el diseño de las actividades culturales, altera el calendario de festividades y, sobre todo, explota de forma suicida el terreno especulando con los fundamentos de la sociabilidad urbana. Sin duda alguna ese conjunto que denominamos 'turismo' es una de las elaboraciones más perfectas y sofisticadas del sistema capitalista por cuanto ha logrado comercializar lo intangible y erigirse en uno de los más efectivos mediadores en la producción de sentidos y significados de la actualidad: de deseos. Porque aunque resulte un trazo excesivamente grueso, las condiciones históricas de esta peculiar manera de combinar el ocio (dimensión tiempo) y el viaje (dimensión espacio) vienen determinadas por los desarrollos del capital y por la ideología que los sustenta: el capitalismo.

En los dos apartados anteriores he sostenido que el turismo coadyuva a la consolidación de un nuevo régimen de la relación espacio-tiempo. En consecuencia, defiendo que el turismo tiene un cronotopo específico porque, aunque los 'hechos' (elementos, objetos, imágenes, motivos) que conforman este 'universo turístico' puedan rastrearse en los mitos clásicos (cf. Dufour, 1977), la lógica con la que estos se refunden, presentan y vinculan unos a otros es nueva. Hablando siempre del 
espacio y el tiempo como productos sociales, el cronotopo del turismo es distintivo porque, en cierto modo y como ilustra el caso del cartel descrito, privilegia la condición espacial frente a la temporal. Me explico.

Aunque el binomio espacio-tiempo sea inextricable, la condición necesaria para calificarlo como turístico es que el discurrir social se realice en un lugar distinto al habitual, es decir, se esté 'fuera de casa: de viaje'. También es cierto que para que ese viaje sea 'turístico', el tiempo tiene que ser "cualitativamente diferente" al cotidiano (Iso-Ahola, 1980). Sin embargo, mientras que es poco habitual que uno actúe en su lugar de residencia (casa) como un turista (vistiendo ropa poco acorde con cada situación, cámara al cuello, acudiendo a 'establecimientos para turistas', adquiriendo recuerdos, comiendo platos combinados o paellas pre-cocinadas en las terrazas, etcétera), sí es bastante probable que cuando Ud. se encuentre de viaje en un territorio que le sea desconocido, los anfitriones le traten (iy las estadísticas que gestionan la Realidad le cuenten!) como un turista independientemente de cuál sea el motivo último de su visita. No se extrañe de esto. Los dispositivos simbólicos (que le incitaron a visitar ese y no otro sitio) y los tecnológicos (que le han permitido llegar sin problema, pernoctar y alimentarse con más o menos comodidad, y encontrar un atractivo que le entretenga: sea leyendo relajadamente sobre un tronco resecado por la humedad mientras runrunea el rumor del arroyo, sea aventurándose por un acantilado bien asegurado con arneses, sea deleitándose con un paseo a través de un 'marco incomparable', o sea apresurándose por cumplimentar todos los hitos que le 'recomienda' la guía del Routard, la Michelin o la que fuera que adquiriese en la librería de su barrio) se complementan para que el viajero piense los 'lugares' ajenos como 'destinos' propios. Esta dualidad lugar-destino es una suerte de exterioridad mutua que los aleja uno de otro de manera irreconciliable.

\subsection{El cronotopo del veraneo}

El rigor científico previene contra el tratamiento textual del Turismo como sujeto si se pretende dar solidez a una caracterización del cronotopo del turismo. Ya he subrayado que las investigaciones sobre turismo están muy influidas por esa literatura que resulta más accesible y recomendada por los índices bibliométricos. En esta literatura el tema u objeto de estudio central es el turismo internacional. No obstante, según indicó Frédéric Pierret, director ejecutivo de la Organización Mundial del Turismo, en una conferencia impartida en Argelia en diciembre de 2010 los economistas de la OMT estiman que el $83 \%$ del total de llegadas de turistas y el $73 \%$ del total de pernoctaciones a nivel mundial corresponde al turismo nacional o intrafronterizo (domestic tourism). Por tanto, cualquier intento de caracterizar de qué manera el Turismo combina el espacio y el tiempo debe tener en cuenta este otro turismo. Especialmente en países como España donde existe una modalidad social de este turismo que cada verano lleva a decenas de miles de familias a trasladarse a su residencia en la costa o en el pueblo de sus mayores: los veraneantes.

${ }^{18} \mathrm{http}$ //unwto.org/en/agora/some-points-domestic-tourism?page $=0,1$ 
Los datos más fiables de los que disponemos para calibrar este fenómeno a nivel del estado son los que provienen del Censo de Población y Viviendas de 2001 que censa 3.360.631 viviendas secundarias y representan un $16 \%$ del total de viviendas familiares ${ }^{19}$. Según el Informe Familitur- 2010 del Instituto de Estudios Turísticos sobre los movimientos turísticos de los españoles, el 20,8\% de los hogares españoles tienen "acceso a una segunda residencia" (pág. 19). De los 148,6 millones de viajes internos (pág. 42), el 53,9\% se realizaron por vacaciones (pág. 55) y el $29 \%$ se alojó en viviendas de su propiedad (pág. 59) ${ }^{20}$.

Desafortunadamente no hay demasiados estudios cualitativos sobre este tema. El estudio de la segunda residencia como fenómeno social y cultural en entornos turísticos, salvo las enmarcadas en la 'sociología de la vivienda' (Ortega, 1973; del Pino, 2003), en el 'turismo residencial' (Aledo, 2008), o en el paradigma de las movilidades y los residentes extranjeros (Mazón, Huete y Mantecón, 2009), no ha sido un objeto de estudio especialmente privilegiado por la política de investigación científico social. La mayoría de los estudios se han realizado desde la geografía y están centradas en las transformaciones del territorio, o desde disciplinas económico-empresariales, preocupadas por el tejido productivo. No tengo conocimiento —aquí también agradecería cualquier corrección - de ninguna etnografía sobre este fenómeno.

Los veraneantes, ¿son turistas? La expresión "veraneante de toda la vida" no es extraña en nuestro contexto y constituye una categoría social en muchos pueblos. Los veraneantes o forasteros siempre han sido bien recibidos en los pueblos. Desde Llanes (Asturias) donde en 1893 ya se daba la bienvenida "a los forasteros que honran con su presencia las fiestas de San Roque ${ }^{21}$ " en el folleto de las fiestas patronales de San Roque, hasta El Puerto de Santa María (Cádiz) donde desde mediados del XIX se agradece la llegada de "la numerosa colonia veraniega que en estos días nos visita" (Nogués, 1999). Hoy son muchos los pueblos que refuerzan lazos identitarios con los que emigraron y aprovechan la vuelta de estos al pueblo durante las vacaciones para celebrar la "fiesta de los veraneantes" como en Valderredible (Cantabria), San Tirso de Abres (Asturias), Moral de la Reina (Valladolid) o Huéscar (Granada).

El diálogo entre vecinos y veraneantes es constante. Cualquier lector interesado puede comprobar en Internet el uso que se hace de la expresión "veraneante de toda la vida". Durante mis trabajos de campo he constatado que siempre se utiliza como fórmula discursiva que introduce y auto-identifica al hablante y que, muy importante, busca la fusión con el interlocutor. Es un elemento lingüístico indispensable porque legitima para hablar sobre lo que ocurre en el pueblo. Es una expresión que pretende situar a los interlocutores en igualdad de condiciones y en un contexto

${ }^{19}$ Un explotación de los datos de este censo muestra las diferencias entre comunidades autónomas y la influencia de la morfología de las ciudades en la relevancia que tiene este fenómeno en España (López, Módenez, Yépez, 2007).

${ }^{20} \mathrm{http}$ ://www.iet.tourspain.es/es-es/documentacionturistica/otraspublicaciones/familitur/ Paginas/default.aspx

${ }^{21} \mathrm{http}: / / w w w . I n e . e s /$ siglo-xxi/2011/04/26/fiestas-patronales-bienvenida-colonia-veraneantes/1065706.html 
de enunciación compartido donde los deícticos puedan desempeñar su papel en la conformación del cronotopo. Los veraneantes se consideran parte del pueblo - y más si la familia es oriunda- porque la mayoría tiene casa en propiedad, pagan los impuestos y tasas municipales, cuidan y miman el espacio común, tienen amistades y comparten los cotilleos y, sobre todo, por el tiempo que llevan haciendo todo lo anterior. Dos ejemplos. En el diario Deia (23/septiembre/2011) un ex-alcalde (PNV) del municipio vizcaíno de Lekeitio elevaba una queja pública sobre los insultos que los concejales y sus familias habían sufrido durante años por parte de "los mismos desconocidos de siempre". Pues bien en un contexto de tanta fuerza simbólica el ex-alcalde refiere que según le habían contado, "un 'veraneante de toda la vida', un prohombre y ex-cargo público de la izquierda abertzale de Bilbao, alardeaba en un bar muy conocido de la capital de que lo primero que ha hecho Bildu al acceder al gobierno en Lekeitio ha sido abrir la puerta principal del ayuntamiento". En circunstancias muy distintas, esta vez en un foro virtual sobre la construcción de un parque infantil en Veguellina de Fondo (León), también encontramos a un "veraneante de toda la vida y durante el año suelo visitarlo de cuatro a cinco veces..." que se queja de lo poco que se preocupan los jóvenes por mantener al pueblo y les da consejos sobre cómo deben actuar los "que lo están dejando morir"22.

Son muchos los ejemplos que podemos encontrar del uso de esta expresión y en circunstancias muy dispares. Aunque en todos los casos se privilegia la reivindicación del tiempo - y la frecuencia como una magnitud que modula y refuerza la calidad de ese tiempo - como fundamento del derecho a ser escuchado en las cosas que afectan al territorio. También espacio y también tiempo. Pero con un tratamiento radicalmente distinto al que se perfilaba en el cronotopo del turismo transfronterizo - cualquiera que sea de las fronteras de las que hablemos: estatales, regionales o municipales. En el 'cronotopo del veraneo', por forzar la terminología, es imposible hablar de exterioridad mutua en el plano espacial porque, tampoco es habitual que el veraneante tenga un sentimiento de pertenencia compartida: de ahí su imbricación en los sucederes de ambos lugares. Aquí los dispositivos simbólicos que construyen lo deseable, y los tecnológicos que facilitan transporte, alojamiento y entretenimiento no intervienen de la misma manera. En el cronotopo del veraneo el 'destino' no es tan ajeno; de hecho, me atrevería a decir que la idea de destino turístico es tan radicalmente distinta a la que esbozan los dispositivos socio-tecnológicos del Turismo ${ }^{23}$ que no existe porque no se piensa como tal. En este caso, lo que establece la exterioridad entre el veraneante y los vecinos del pueblo son las formas sociales y culturales que se producen en torno a la noción de una identidad que es modelada por el ritmo de lo cotidiano.

Debo traer un ejemplo para ilustrar el argumento. Uno de mis informantes principales en Zahara de los Atunes escribió el pregón de las Fiestas de Verano de 1990 y no dudó al trazar la identidad local:

${ }^{22} \mathrm{http} / /$ www.foro-ciudad.com/leon/veguellina-de-fondo/mensaje-8667006.html

${ }^{23}$ El caso de Torrevieja y los apartamentos que regalaban en el Un, dos, tres, aquel famoso concurso televisivo de los setenta, merece un tratamiento tal que excedería los propósitos de este artículo. 
"En Zahara hay dos clases de zahareños, el nacido aquí y el que lleva años viniendo y se siente zahareño, e incluso algunos quieren ser más zahareños que el nacido aquí. Todos dicen: 'Yo llevo viniendo a Zahara desde el año tal, y yo desde el año tal', y cuantos más años lleve viniendo, mejor para ellos, y eso es un orgullo para nosotros. Pero ser zahareño es otra cosa, no es venir desde hace años a veranear, ni pasar algunos fines de semana aquí. Ser zahareño es como dice la copla: 'no se puede ser zahareño si nunca ha estado en sus playas en una tarde de invierno estando la mar muy brava', es bonito el verano, las noches de levante en calma, las fiestas, la playa, pero el año es muy largo y los inviernos muy duros y para algunas familias casi inaguantables, el coger tagarninas para ir tirando, coger caracoles, rebuscar garbanzos, etc."

En el cronotopo del veraneo la diferencia entre veraneantes y vecinos no estriba, como vemos, ni en los usos uso del espacio ni en los del tiempo, sino en el ritmo de lo cotidiano. En la cadencia con la que suceden las cosas y sus repeticiones. En el suceder de la participación, que es lo que conforma el sentido de lo diario y que, en su hacer expresivo, hermosea al territorio transformándolo en paisaje ${ }^{24}$. Un paisaje que es único porque solo en él se encuentra lo que distingue al veraneante del vecino: la memoria. Y la memoria solo adquiere sentido cuando es compartida y reforzada en los quehaceres diarios. Analizada en esta perspectiva, la categoría ideal 'veraneante' es más cultural que social porque trata de la diferencia - lo cultural de Arjun Appadurai. Las categorías ideales de 'vecino', 'veraneante' y 'turista', porque son excluyentes, conforman el continuum de las distintas maneras en las que las prácticas sociales, enmarcadas en combinaciones particulares de los elementos espaciales y temporales, transforman un mismo territorio en paisajes distintos.

Por el contrario, en el turismo transfronterizo los dispositivos socio-tecnológicos despersonalizan llamando 'destino' lo que para los vecinos constituye la realidad más concreta, distintiva e intransferible de su ser social: la cédula de identificación de los grupos culturales: el territorio; y el soporte de los sueños y deseos que son la vida: el paisaje. No puede extrañarnos pues que, de igual manera que se utiliza la palabra contra los habitantes de los territorios, también estos — que construyen su día a día a través de la mediación significativa del espacio turístico (Nogués, 2008) - hayan dejado de servir a los extranjeros (xenos) bajo las antiguas reglas de la hospitalidad y los traten de acuerdo con las leyes que rigen el intercambio de mercado como 'turistas' (Zarkia, 1996). Esta despersonalización del visitante-turista que se produce cuando se le integra en un mismo grupo independientemente de los motivos originales que le llevaran allí (negocios, putas, monumentos, congresos, indígenas, peregrinaciones o playas... ¡motivos estos no necesariamente excluyentes!) no es, sin embargo, exclusivo de los autóctonos. Muy al contrario: somos muchos los que embelesados ante la enormidad de las cataratas del Niágara nos estorban los barquitos llenos de chubasqueros amarillos que afean la imagen, o nos quejamos

${ }^{24}$ Escribe Mandly: "sobre un espacio las culturas construyen sus territorios, los señalan con deícticos, los dotan de topónimos y prosopónimos los cualifican en términos de creencias, valores, ideologías, les dan sentido. Así los transforman en lugares cuando los hermosean o deterioran, viven y recuerdan" (Mandly, 2002:108). 
al no poder sentir el recogimiento del cementerio judío de Praga por la cantidad de "turistas que hay", o nos incomodamos por la larga espera que antecede el deleite de una paella en la Malvarrosa valenciana por "los turistas que lo invaden todo". De acuerdo con el cronotopo del turismo transfronterizo los 'destinos' no son vividos porque son construidos para el disfrute individual de cada visitante: de ahí que su uso tenga un fuerte carácter de exclusividad y el ritmo se oponga directamente al de los vecinos. Por el contrario, en el cronotopo del veraneo, la dimensión espacial solo tiene sentido - es decir, paisaje - si hay gente con la que vivirla, con la que compartirla, también en su ritmo. De hecho, muchas etnografías describen la dialógica que subyace en la adaptación de las relaciones sociales de los vecinos a los nuevos ritmos y espacios generados por el ciclo productivo que impone la llegada de visitantes (Boissevain, 1982).

Aunque hablo en términos graduales, en ambos casos se manifiesta una cierta supeditación del tiempo al espacio como muestra la coexistencia de, al menos, dos mundos recreados en distintos 'juegos del lenguaje' (Wittgenstein). Lo que unos consideran 'lugar', otros lo llaman 'destino'. Lo que unos llaman 'turista', otros lo llaman 'visitante'. Lo que para unos es un juego, para otros es 'auténtico' (cf. Clastres, 1971). Afirmo esto porque para la cualificación del tiempo como 'turístico', esto es, para que a través del uso que se haga del tiempo se le confiera a este la categoría de 'tiempo para el disfrute y la cumplimentación del deseo', es requisito previo la movilidad en el espacio: es necesario que estemos 'fuera de casa: de viaje'. Esta supeditación al espacio de la cualificación social del tiempo como 'de ocio', en su acepción de condicionar algo al cumplimiento de otra cosa, convierte al cronotopo del turismo en objeto de investigación de las ciencias sociales y humanas. Porque es, además, en este particular régimen de producción del espacio y el tiempo que encuentran su sentido social las infinitas denominaciones que recibe la gestión de los flujos de capital: turismo urbano, turismo rural, de aventura, ecoturismo, de congresos, de incentivo, sexual, etcétera.

Según lo veo, dado que solo podemos observar qué significan los hechos que constituyen el mundo cuando son hechos, es decir, una vez han sido ejecutados en un tiempo y un espacio, me parece coherente seguir a Weber y decir que lo único que podemos intentar inferir es el sentido que ha orientado el hecho (acción) que observamos. Desde mi posición teórica no existe un a priori semiotizable que permita conocer el significado de los 'hechos' (elementos, objetos, imágenes, acciones) o analizar el poder de seducción del discurso orientalizante en un eterno desentrañamiento de conceptos como 'autenticidad', 'exótico', 'atracción', 'alterotropía' y que retroalimentan eso que Dann llama 'las lenguas del turismo'.

Este constante uso en contextos turísticos de las palabras, no como elementos de comunicación sino como otra tecnología para la gestión y la producción de Realidad, nos recuerda la dualidad de los mundos del habla de Agustín García Calvo, y nos indica que los enfoques dialógicos son una buena opción para comprender el turismo desde las ciencias sociales y humanas y para enfrentar la prevalencia de los esquemas impuestos por las disciplinas económico-administrativas. Los modelos socio-antropológicos que insisten en estudiar el fenómeno del turismo en términos 
de impacto, pérdida de identidad o mercantilización de la cultura no explican satisfactoriamente cómo a pesar de los años de presencia de la industria turística con todos sus dispositivos de dominación técnico-simbólica, los 'destinos' siguen diferenciándose unos de otros y las 'sociedades receptoras' mantienen su distintividad cultural. La única posibilidad metodológica para explicar esta 'anomalía' (Kuhn) es plantear un acercamiento dialógico que comprenda cómo se generan los sentidos que adquieren los hechos para visitantes (turistas/veraneantes) y vecinos, y que van a orientar sus acciones. Porque con los mismos elementos enunciativos que conforman el discurso turístico (palmera, diversión, aventura, sexo, cultura, mitologías, etcétera), que esculpen el paisaje de deseo e incitan a viajar, y que podemos encontrar en cualquier folleto o guía de cualquier agencia o web de turismo, se produce sobre el terreno un resultado socio-cultural distinto en cada territorio: porque diferentes son las sociedades receptoras sobre los que se aplican pese al uso de la noción de destino que los homogeneiza sobre el papel. Ergo algún papel juegan las sociedades receptoras: sus instituciones, sus tradiciones, sus gentes... su cultura, en definitiva.

Es en este plano que entiendo que en aquellos contextos donde las potencialidades económicas del turismo se presentan como el único medio para gestionar la Realidad o en sitios donde su único sentido se adquiere a través de una realidad turística, es fundamental estudiar las características especiales que adquieren esas condiciones históricas de la expresividad de los grupos humanos que llamamos 'cronotopo'. Por esto, esculpir el paisaje berlinés con el deseo de conocer París solo encuentra su pleno sentido narrativo en un cronotopo que condiciona la ocurrencia (y disfrute) del tiempo turístico a la exigencia de una movilidad previa. "Saludos desde París" habrían tuiteado desde su móvil algunos de los turistas, o "vamos a contar que también estuvimos en París" se habrían dicho mientras se fotografiaban asumiendo el simulacro y el espectáculo. El cartel no solo había consumado el eje Berlín-París como el motor económico e ideológico de la Unión Europea sino deslocalizado también mi propia experiencia del viaje a Berlín... ¿o fue a París?

\section{El turismo y la antropología en un mundo globalizado}

Esta deslocalización de la experiencia transnacional unido al continuum de las categorías ideales vecino-veraneante-turista me llevan, como conclusión, a escribir algún pensamiento nacido de mi experiencia de campo en entornos turísticos sobre la inteligibilidad y distintividad de la práctica etnográfica. O dicho con otras palabras: unas precisiones sobre los retos de hacer trabajo de campo en lugares donde el Turismo, sea transfronterizo o sea de veraneo, es el definidor de la realidad.

La expansión del turismo a finales de la década de los setenta y el cuestionamiento de la autoridad etnográfica en los ochenta parecen dos circunstancias independientes entre sí. Aparentemente no existe ninguna relación de causalidad que permita una conexión sensata entre ambas. Sin embargo son varios los antropólogos que desde hace décadas piensan en la relación entre las prácticas etnográficas y las turísticas.

Pensando sobre los motivos por los que la antropología no prestaba atención suficiente al estudio del turismo, Jeremy Boissevain estuvo entre aquellos que 
plantearon la conexión entre el quehacer antropológico y el turismo. Su experiencia de campo en entornos turísticos le había llevado a concluir que el rechazo que sentían los antropólogos por el estudio del turismo tenía "que ver, pienso, con el deseo de realizar trabajo de campo en comunidades rurales tradicionales, alejadas de emplazamientos turísticos y, por tanto generalmente aisladas. Y aún más, desde Malinowski los antropólogos han sido conocidos por ignorar a los dueños de plantaciones, a los misioneros, a los oficiales coloniales que actuaban en las comunidades que ellos describían. Se consideraba que interferían las costumbres tradicionales que los antropólogos estudiaban. ¿Deben ser los turistas incluidos en esta lista?" (1986:1). Del mismo modo Dennison Nash identifica el disgusto de los antropólogos a ser identificados con turistas como una de las cuatro posibles razones para explicar el porqué de este distanciamiento de la disciplina respecto al estudio del turismo (1981:461). También por aquellos años Malcolm Crick (1985) analizó esta relación de forma directa. No obstante, creo que fue Nigel Barley el primero que, con varias referencias al turismo, admite sin reservas que "durante toda la temporada que estuve en África quizá pasé un uno por ciento del tiempo haciendo lo que iba a hacer" (Barley 1991:125). Por el contrario, Claude Lévi-Strauss tenía muy clara la distinción en los años cincuenta cuando comenzó Tristes Tropiques diciendo que detestaba los viajes y a los viajeros.

Preocupado por esclarecer el papel del turista desde la psicología social, Pearce diferencia quince categorías ideales de viajeros (1982:28-37). Entre otras muchas tales como atleta, estudiante, misionero, peregrino, periodista, emigrante..., también incluye la figura del antropólogo. Con la aplicación de estadísticos (fuzzy-set, análisis multidimensional) perfiló los comportamientos más relevantes que se adscriben a cada una de esas categorías. Los que nos interesan aquí y ahora son los comportamientos del turista y los del antropólogo. El turista toma fotografías, va a lugares famosos, compra souvenirs, contribuye a la economía local y no entiende a la población local. El antropólogo, por su parte, observa la sociedad nativa, explora los lugares de forma privada, está interesado en el medio ambiente, toma fotografías y no compra recuerdos del lugar. Bien. Los papeles están claros y los comportamientos también. Pero ¿diferencian los nativos/vecinos a uno de otro?

La siguiente ilustración apareció en el tablón de anuncios de la biblioteca del, por entonces, Departamento de Antropología Social, Sociología y Trabajo Social en la Universidad de Sevilla cuando tenía mi tesis doctoral casi cerrada. El encabezamiento de aquella fotocopia escrito con rotulador rojo rezaba: "antropólogo = turista". Apenas tuve tiempo de fotocopiarla para incluirla junto a unos breves párrafos de análisis que, en la distancia del hoy, me resultan casi ajenos.

La fotografía había aparecido el 29 de marzo de 1994 en el periódico El Pais ${ }^{25}$. El pie de foto era inequívocamente descriptivo: "Un turista fotografía a los nazarenos de San Gonzalo". Ni la imagen ni el pie de foto serían relevantes si el turista que aparece en la foto no fuese Stanley Brandes, profesor de antropología en la

${ }^{25}$ Agradezco al periódico El País su permiso para reproducir esta fotografía, así como haberme facilitado una reproducción de mayor calidad que la antigua fotocopia que yo guardaba. 


\section{Urgidos por el amor}

Cada cofradía aporta su matiz al día más dulce y calmo de la semana
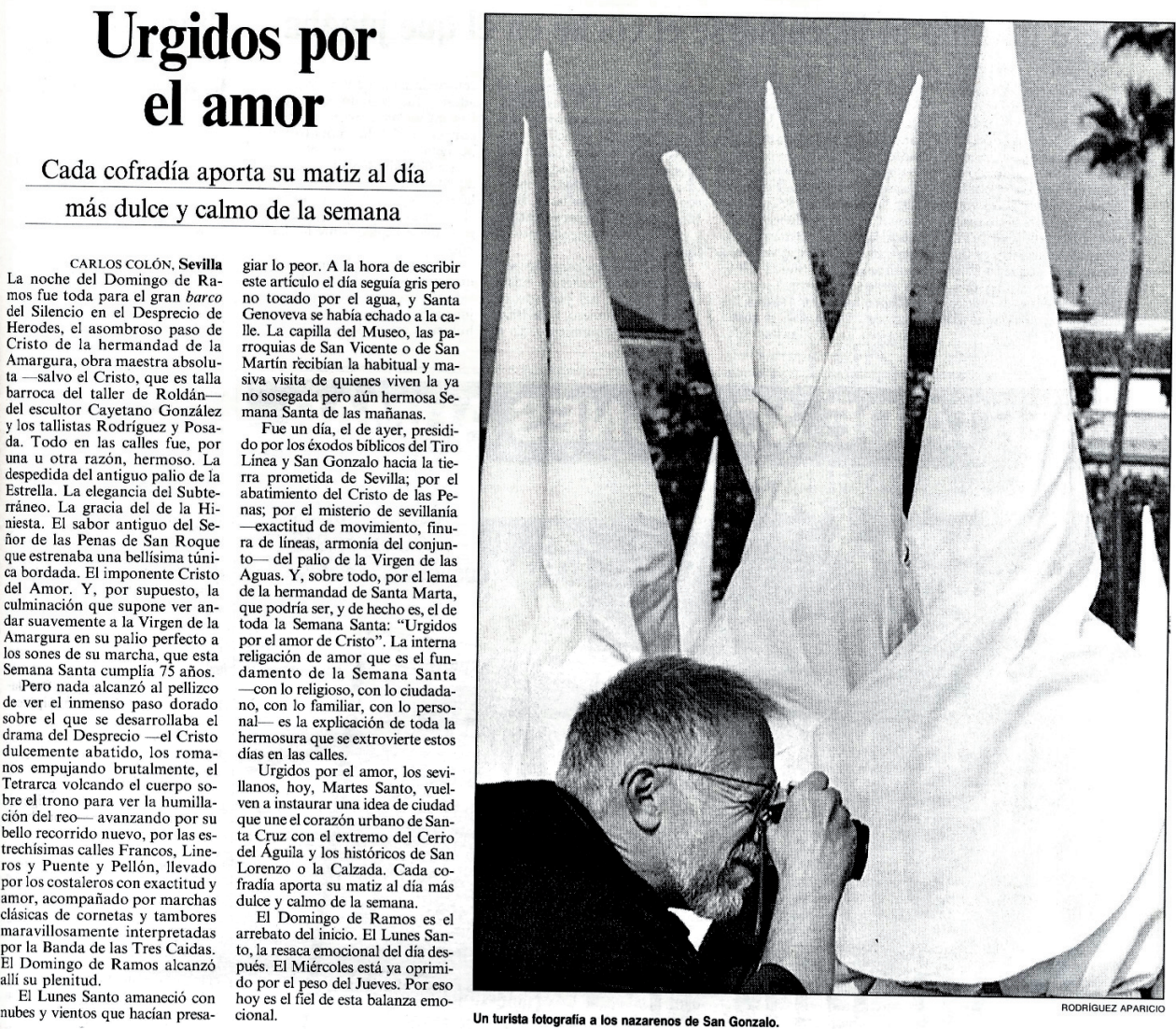

Figura 2. Una experiencia contextualizada: ¿antropólogo o turista?

Universidad de California en Berkeley (EE.UU.) y autor de varios trabajos etnográficos en la Península Ibérica (Brandes, 1991). Y ni siquiera esto tendría demasiada relevancia si no fuera porque, un par de años después, publicó un artículo sobre la imagen fotográfica en España (Brandes, 1996). Considerando esto, es lícito que preguntemos, como hiciera de manera reflexiva Barley sobre su propio trabajo, si Brandes 'hacía antropología' o 'hacía turismo'.

La respuesta no es importante para el argumento. Y no lo es porque de la misma manera que las comunidades lidian con los turistas, generando nuevas prácticas y significados (Boissevain, 1996; Nogués, 2011), la fotografía ilustra que en ese contexto un señor con un indubitable aspecto de extranjero que toma una fotografía en la Semana Santa de Sevilla, encumbrada fiesta de interés turístico internacional, no puede no ser otra cosa que un turista. Como tal es categorizado y tratado por los 
nativos. En consecuencia: ¿cómo tomaríamos y qué tipo de respuesta le daríamos si, estando junto a él, nos preguntase algo sobre la celebración que ambos observamos? ¿Tendríamos los antropólogos que considerar, también, nuestro fenotipo como variable para comprender mejor el contexto de enunciación de los relatos de los informantes en entornos turísticos?

Nadie duda que las categorías de antropólogo y turista sean distintas porque los motivos que las ocasionan y el sentido que orienta las acciones son radicalmente diferentes. Sin embargo, también es cierto que adquieren cierta similitud cuando, al entender de las gentes del lugar, los usos del espacio y del tiempo se asemejan bastante. He intentado demostrar que el cronotopo del turismo se distingue por una visualización del tiempo en el espacio, es decir, por la subordinación del goce del tiempo de ocio - plasmado en un ritmo peculiar - a que se esté en un lugar distinto al habitual. Pero el Turismo no es solo una forma de ocupar el espacio y de entretener el tiempo sino, como muestra este caso, también un contexto donde se significan las ideas y se concretan los términos que fundamentan su propia expansión global.

Mi experiencia de campo en entornos turísticos globalizados donde el continuum de categorías culturales se enriquece (inmigrantes, extranjeros, residentes, turistas, españoles, veraneantes, gent del poble,...) me dice que la categoría más académica solo aparece clara y distinta cuando, al igual que ocurre con la de 'veraneante', hayamos pasado el suficiente tiempo compartiendo el ritmo de lo cotidiano con aquellos a los que queremos comprender. Creo que esto obliga a reflexionar sobre el quehacer antropológico en sus métodos y sus técnicas. Y especialmente en una situación actual en la que el "capitalismo académico" impone, por un lado, un ritmo frenético en la transferencia de resultados de investigación que impide tanto el trabajo de campo de larga duración como la reflexión crítica sobre nuestra sociedad; por otro, el seguimiento (o trazabilidad) y la contabilidad de estos resultados como único criterio para consolidar una carrera profesional en la universidad; y, por último, invita a reorientar la práctica antropológica hacia la producción de informes etnográficos que muestren la utilidad de la disciplina de acuerdo con los indicadores de capitalización de la investigación. Circunstancia que coadyuva a que la distinción entre categorías en entornos turísticos sea cada día más fluida y difusa.

Esta es una posición que se complementa bien con la descripción que hace Javier Escalera y que no me resisto a reproducir in extenso para finalizar este artículo: "Cuando además el logro de determinadas metas académicas viene determinado por el número de 'impactos' en un determinado tiempo y ello se establece además en un marco competitivo, la carrera por obtener lo antes posible los objetivos establece el puro cálculo de coste/beneficio como la lógica que determina la actividad investigadora. No es extraño por ello que, no sólo en Antropología, pero especialmente en nuestra disciplina, cada vez sean menos las investigaciones de largo plazo, imponiéndose, en el mejor de los casos, las etnografías express, cuando no el refrito o el salto directo a la interpretación sobre materiales de segunda mano. Las dificultades para la obtención de la financiación adecuada que permita la realización de un trabajo de campo de tempo largo es un factor que contribuye a ello, pero ni mucho menos el único, ni siquiera, desde mi punto de vista, el más importante. En 
mi opinión, este desapego de la etnografía, del trabajo de campo etnográfico, es uno de los principales peligros que amenazan la propia continuidad de la Antropología como disciplina y, de paso, la pérdida de una de sus principales aportaciones a la posibilidad de profundizar en el conocimiento de la realidad en la que vivimos" (Escalera, 2011:143-144).

Si he conseguido mostrar la distintividad de los entornos turísticos globalizados porque en ellos rige una combinación particular de los depositarios del binomio espacio-temporal (cronotopo), y que esto difumina la línea que separa el territorio turístico del lugar etnográfico, quizás este artículo haya satisfecho los principios de esa 'epistemología ecológica' que a veces resulta tan necesaria para corregir la saturación de publicaciones científicas que sufrimos.

\section{Referencias bibliográficas}

ALEDO TUR, Antonio

2008 "De la tierra al suelo: la transformación del paisaje y el nuevo turismo residencial". Arbor: Ciencia, pensamiento y cultura, 729: 99-113.

BAJTíN, Mijaíl

1989 [1937] Teoría y estética de la novela, págs. 237-409. Madrid: Taurus.

BARLEY, Nigel

1991 [1983] El antropólogo inocente. Barcelona: Anagrama.

BERGER, Peter; LUCKMANN, Thomas

1991 [1966] La construcción social de la realidad. Buenos Aires: Amorrortu editores.

BOISSEVAIN, Jeremy

1982 'Variaciones estacionales sobre algunos temas mediterráneos'. Ethnica, 18:51-58.

1986 Tourism as anti-structure. Euromed Working Paper, $\mathrm{n}^{\circ} 43$.

2011 [1996] Lidiar con turistas. Reacciones europeas al turismo en masa. Bellaterra edicions, Barcelona.

BRANDES, Stanley H.

1991 "España como 'objeto' de estudio: reflexiones sobre el destino del antropólogo norteamericano en España”, en J. Prat, I. Moreno, U. Martínez Veiga y J. Contreras Hernández (coords.) Antropología de los pueblos de España. Madrid: Taurus editorial, 141-150.

1996 "La fotografía etnográfica como medio de comunicación", en Las diferentes caras de España: perspectivas de antropólogos extranjeros y españoles. A Coruña: Universidade da Coruña, Servicio de Publicaciones, 55-88.

BRITTON, Stephen G.

1982 "The political economy of tourism in the Third World". Annals of Tourism Research, 9(3): 331-358.

CLASTRES, Pierre

1987 [1971] "La atracción del crucero", en ibid. Investigaciones en antropología política, México: Gedisa, 47-52. 
CRICK, Malcolm

1985 "'Tracing' the anthropological self: quizzical reflections on field work, tourism and the ludic". Social Analysis, 17:71-92.

1989 "Representations of international tourism in the social sciences: sun, sex, sights, savings, and servility". Annual Review of Anthropology, 18:307-344.

DANN, Graham H.

1996 The language of tourism: a sociolinguistic perspective. Wallingford: Cab International.

DEL PINO ARTACHO, Julio A.

2003 “Aproximación sociológica a la vivienda secundaria litoral”. Scripta Nova: Revista electrónica de geografía y ciencias sociales, VII-146(026).

DUFOUR, Roland

1977 Des mythes du loisir/tourisme. Week-end: aliénation ou libération?Aix-en-Provence: Université de Droit, d'Economie et des Sciences, Centre des Hautes Études Touristiques, Série C, vol. 47.

DUIM, René van der

2008 "Exploring Pro-poor Tourism Research: The State of the Art", en H.J. de Haan, y R. van der Duim (cords.) Landscape, leisure and tourism; socio-spatial studies in experiences, practices and policies, Delft: Eburon Academic Publishers, 179-196.

ESCALERA REYES, Javier

2011 "Reivindicación de la etnografía: a propósito de una primera experiencia etnográfica en la Sierra de Cádiz", en A.M. Nogués y F. Checa (coords.) La cultura sentida. Sevilla: Signatura ediciones, 139-144.

GASCÓN, Jordi

2009 El turismo en la cooperación internacional. Barcelona: Icaria-Antrazyt.

GAVIRIA LABARTA, Mario

1974 España a go-gó. Turismo charter y neocolonialismo del espacio. Madrid: Ediciones Turner.

GIDDENS, Anthony

1990 The consequences of modernity. Stanford: Stanford University Press.

JURDAO ARRONES, Francisco

1992 [1979] España en venta. Compra de suelos por extranjeros y colonización de campesinos en la Costa del Sol. Madrid: Endymion.

HOFFMAN, Steve G.

2011 "The new tools of the science trade: contested knowledge production and the conceptual vocabularies of academic capitalism". Social anthropology/Antropologie sociale, 19: 439-462.

ISO-AHOLA, Seppo E.

1980 The social psychology of leisure and recreation. Dubuque: Drown Company Publishers. 
LALLIER, Christian

2001 Chambre d'hôtes dans le Sahel. Documental co-producido por Gédéon Programmes-Arte France Cinéma.

LÓPEZ COLAS, Julián; MÓDENES CABRERIZO, Juan Antonio; YÉPEZ MARTÍNEZ, Brenda

2007 "Los usuarios de residencias secundarias en España: perfiles regionales". Boletín de la asociación de geógrafos españoles, 45: 307-325.

MANDLY ROBLES, Antonio

1977 Costa del Sol. Retrato de unos colonizados. Madrid: Campo Abierto Ediciones.

2002 "Espacios, lugares, transparencias", en M. Luna (ed.), La ciudad en el tercer milenio. Murcia: Universidad Católica San Antonio, 109-132

MAZÓN, Tomás; HUETE, Raquel; MANTECÓN, Alejandro. (Coords.)

2009 Turismo, urbanización y estilos de vida: las nuevas formas de movilidad residencial. Barcelona: Icaria.

MEETHAN, Kevin

2003 "Mobile cultures? Hybridity, tourism and cultural change". Tourism and cultural change, 1 (1): 11-28.

MORAGUES CORTADA, Damián

2007 Turismo, cultura y desarrollo. Madrid: AECID.

NASH, Dennison

1989 [1978] "Tourism as a form of imperialism", en V. Smith (ed.) Hosts and guests: the anthropology of tourism, $2^{\mathrm{a}}$ ed. Philadelphia: University of Pennsylvania Press, 37-52.

1981 “Tourism as an anthropological subject". Current anthropology, 22(5):461-481.

NOGUÉS PEDREGAL, Antonio Miguel

1999 "Una aproximación desde la antropología a la historia del turismo portuense como estrategia de desarrollo local". Revista de historia de El Puerto, 23: 31-51.

2008 "Poder político local y urbanismo en entornos turísticos. La mediación del espacio turístico en la producción de significados". Gazeta de antropología, 24.

2011 "Prólogo a la edición española. La antropología entre lo cultural y el turismo", en J. Boissevain (coord.) Lidiar con turistas. Reacciones europeas al turismo en masa. Barcelona: Bellaterra edicions, 9-25.

NOGUÉS PEDREGAL, Antonio Miguel; SOLER GARCÍA, Cristina; CABALLERO SEGARRA, Eva

2010 "Turismo y (cooperación al) desarrollo: qué papel desempeña la cultura en esta relación". I Congreso COODTUR - Red Internacional de Investigadores en Turismo, Cooperación y Desarrollo. Tarragona: Universitat Rovira i Virgili.

SOLER GARCÍA, Cristina; CABALLERO SEGARRA, Eva; NOGUÉS PEDREGAL, Antonio Miguel

2010 "Cultura, turismo y desarrollo, o cómo la cultura se diluye con el patrimonio en los contextos de desarrollo". IV Congreso Internacional de Patrimonio Cultural 
y Cooperación al Desarrollo. Sevilla: Instituto Andaluz del Patrimonio Histórico, 389-394.

O'ROURKE, Dennis

1988 Cannibals Tours. Documental producido por Camerawork L.J. Henderson \& Chris Owen

ORTEGA VALCÁRCEL, José

1975 Residencias secundarias y espacio de ocio. Valladolid: Departamento de Geografía, Universidad de Valladolid.

OOI, Can-Seng

2002 Cultural tourim and tourism cultures. The business of mediating experiences in Copenhagen and Singapore. Copenhagen: Copenhagen Business School Press.

PEARCE, Philip L.

1982 The social psychology of tourism behaviour. Oxford: Pergamon Press.

WRIGHT, Susan; RABO, Annika

2010 "Introduction: anthropologies of university reform", Social anthropology/ Antropologie sociale, 18:1-14.

ZARKIA, Cornélia

2011 [1996] "Philoxenia: recibiendo a turistas — no huéspedes — en una isla griega", en J. Boissevain (coord.) Lidiar con turistas. Reacciones europeas al turismo en masa. Barcelona: Bellaterra edicions, 223-257. 